Jurnal Basicedu Volume 3 Nomor 4 Tahun 2019 Halaman 2009-2015

JURNAL BASICEDU

Research \& Learning in Elementary Education

https://jbasic.org/index.php/basicedu

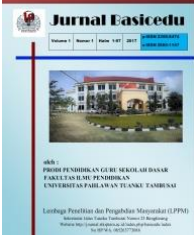

\title{
PENINGKATAN KEMAMPUAN BERKOMUNIKASI MATEMATIKA MELALUI MODEL PROBLEM BASED LEARNING DI SEKOLAH DASAR
}

\author{
Serly Verawati Nubatonis ${ }^{1}$, Henny Dewi Koeswanti ${ }^{2}$, Sri Giarti ${ }^{3}$ \\ Universitas Kristen Satya Wacana, Jawa Tengah, Indonesia ${ }^{1,2,3}$ \\ Email : 292015145@student.uksw.edu¹, dewi@ staff.uksw.edu ${ }^{2}$, sgiarty@gmail.com ${ }^{3}$
}

\begin{abstract}
Abstrak
Tujuan penelitian ini adalah meningkatan kemampun berkomunikasi Matematika pada siswa kelas 5 SD St.Theresia Marsudirini 77 Salatiga Tahun Pelajaran 2019/2020 menggunakan model Problem Based Learning. Adapun jenis penelitian yang di gunakan adalah penelitian tindakan kelas. Dengan Subjek penelitian adalah siswa kelas 5 SD St.Theresia Marsudirini 77 Salatiga berjumlah 44 siswa. Teknik pengumpulan data yang di gunakan adalah tes dan non tes observasi wawancara analisi data deskriptif kualitatif. Hasil penelitian menunjukan bahwa ada peningkatan kemampuan berkomunikasi Matematika sebesar $47.7 \%$ pada siklus 1 dan pada siklus II 79,5\%.
\end{abstract}

Kata Kunci: Kemampuan Berkomunikasi Matematika, Model Problem Based Learning

\begin{abstract}
Abstrack
The aim of this study is to improve Mathematical communication skills in 5th grade students St.Theresia Marsudirini 77 Salatiga Academic Year 2019/2020 use "model Problem Based Learning”. the type that used in this research is classroom action research. The subject of the research was 11 students in grade 5 of SD St.Theresia Marsudirini 77 Salatiga. Data analysis techniques used are tests and non-tests. The results showed that there was an increase in the ability to communicate Mathematics by $47.7 \%$ in first cycle and in the second cycle is $79.5 \%$.
\end{abstract}

Keywords: communication skills, Problem Based Learning Mathematics

@ Jurnal Basicedu Prodi PGSD FIP UPTT 2019

Corresponding author:

Address :

Email :

ISSN 2580-3735 (Media Cetak)

Phone

ISSN 2580-1147 (Media Online) 
2010 Peningkatan kemampuan berkomunikasi matematika melalui model PBL di sekolah dasar - Serly Verawati Nubatonis, Henny Dewi Koeswanti, Sri Giarti

\section{PENDAHULUAN}

Pemberlakuan kurikulum 2013 membuat konsekuensi yang tidak ringan bagi sekolah maupun peserta didik. Ada beberapa persiapan yang harus dilakukan sekolah, diantaranya persiapan sumber daya manusia guru, pengkondisian siswa dan penyedia sarana prasarana. guru tidak hanya berfungsi mentransfer pengetahuan saja tetapi juga bertugas untuk memberikan keterampilan, merubah perilaku peserta didik (Suhandi Astuti, 2016:117). Persyaratan sumber daya manusia terutama berkaitan dengan kemampuan guru dalam menguasai dan menerapkan model-model pembelajaran dengan berbagai pendekatan terutama pendekatan saintifik (pendekatan ilmiah). Pernyataan ini sesuai dengan ketentuan dalam Lampiran Permendikbud No. 22 Tahun 2016 tentang Standar Proses Pendidikan Dasar dan Menengah menyatakan bahwa salah satu dari prinsip pembelajaran adalah perlunya pergeseran model pembelajaran dari yang tekstual menuju pembelajaran yang mengutamakan proses sebagai penguatan pendekatan ilmiah atau saintifik (Kemdikbud, 2016: 2).

Pendekatan Saintifik merupakan pendekatan pembelajaran ilmiah ini menekankan pada pentingnya kolaborasi dan kerjasama di antara peserta didik. Majid (2014: 193) mengungkapkan bahwa penerapan pendekatan saintifik bertujuan untuk pemahaman kepada peserta didik dalam mengenal, memahami berbagai materi menggunakan pendekatan ilmiah, bahwa informasi dari mana saja, kapan saja, dan tidak tergantung pada informasi searah dari guru. Daryanto (2014:51) mengungkapkan bahwa pembelajaran dengan pendekatan saintifik adalah proses pembelajaran yang dirancang sedemikian rupa agar peserta didik secara aktif mengkonstruksi konsep, hukum atau prinsip melalui tahapan - tahapan mengamati, merumuskan masalah, mengajukan atau merumuskan hipotesis, mengumpulkan data dengan berbagai hukum, menganalisis data, menarik kesimpulan dan mengkomunikasikan konsep, hukum atau prinsip-prinsip yang ditemukan.

Berdasarkan pendapat tersebut disimpulkan bahwa pendekatan saintifik merupakan pendekatan yang berpusat kepada siswa agar siswa dapat secara aktif mengkontruksi konsep, hukum atau prinsip-prinsip melalui tahapan - tahapan mengamati, merumuskan masalah, mengajukan atau merumuskan hipotesis, mengumpulkan data dengan berbagai hukum, menganalisis data, menarik kesimpulan dan mengkomunikasikan konsep, hukum atau prinsip yang ditemukan.

Pembelajaran pada kurikulum 2013 merupakan penerapan dari pembelajaran abad-21. Pembelajaran ini menekankan pada kemampuan 4C yaitu Communication, Collaboration, Critical Thinking and Problem Solving, dan Creativity and Innovation. Salah satu kemampuan 4C yang diperlukan dalam muatan matematika adalah kemampuan komunikasi. Hal ini dikarenakan matematika merupakan suatu pelajaran yang tersusun secara beraturan, logis, berjenjang dari yang paling mudah hingga ke paling rumit. Sedangkan pembelajaran matematika pada hakikatnya adalah proses yang sengaja dirancang dengan tujuan untuk menciptakan suasana lingkungan memungkinkan seseorang (siswa) melaksanakan kegiatan belajar matematika, dan proses tersebut berpusat pada guru mengajar matematika (Sri Giarti, 2014: 3).

Sedangkan kemampuan berkomunikasi menurut Hosan (2015: 94) adalah sebuah kegiatan mentransfer sebuah informasi baik secara lisan maupun tulisan. Widjaja (2008: 1) menjelaskan bahwa komunikasi adalah hubungan kontak antar dan antara manusia baik individu maupun kelompok. Dalam kehidupan sehari-hari itu sendiri 
manusia sejak dilahirkan sudah berkomomnikasi dalam lingkungan. Suprato (2011: 5) mengutip pendapat dari Joseph A. Devito yang menyatakan bahwa komonikasi adalah transaksi, dengan transaksi dimaksudkan bahwa komonikasi merupan suatu proses dimana komponenkomponennya saling terkait, dan bahwa paraberkomunikasi beraksi dan bereaksi sebagai suatu kesatuan dan keseluruhan.

Berdasarkan beberapa teori yang sudah dijelaskan sebelumnya tentang pengertian ketrampilan berkomunikasi siswa, Inge Hutagalung (2007: 68), menyakan indikator kemampuan berkomonikasi dilihat dari aktifitas siswa yang meliputi: (1) kemampuan berkokomunikasi verbal, meliputi melakukan diskusi, mempresentasikan hasil diskusi, menyampaikan pendapat, menjawab pertanyaan, menuliskan hasil akhir diskusi, tata bahasa yang baik, pembicara singkat, jelas dan mudah dimengerti serta suara terdengar jelas; (2) kemampuan bekomunikasi nonverbal meliputi : melihat lawan bicara, ekspresi waja yang ramah dan gerakan tangan yang sesuai dengan kata-kata yang diucapkan.

Berdasarkan pendapat para ahli di atas dapat disimpulkan bahwa proses komonikasi merupakan suatu proses berinteraksi atau terjadinya transaksi dengan maksud dimana komponen-komponen saling terkait dan para komunikator beraksi dan beraksi. Pentingnya kemampuan komunikasi siswa pada pembelajaran matematika menuntut guru untuk lebih kreatif. Pembelajaran haruslah berfokus pada siswa dan bukan pada guru. Dengan demikian kemampuan berkomunikasi siswa dapat meningkatnya kemampuan berkomunikasi maka hasil belajarnya akan meninggkat.

Berdasarkan hasill observasi di SD St.Theresia Marsudirini 77 Salatiga yang dilakukan pada tanggal 17 Januari 2019 ditemukan bahwa guru masih menggunakan metode atau model pembelajaran ceramah, hal ini menyebabkan siswa cenderung pasif, hanya mendengarkan penjelasan guru serta mengerjakan soal - soal yang diberikan oleh guru. Sehingga hal ini berdampak pada rendahnya kemampuan berkomunikasi siswa (Astuti 2017: 49).

Rendahnya tingkat kemampuan berkomunikasi siswa ditunjukan melalui data kemampuan berkomonikasi yang diperoleh dari hasil observasi kelas 3 SD $\quad$ St. Theresia Marsuddirini 77 salatiga semester I tahun ajaran 2019/2020 yakni dari 30 siswa kelas 3, belum ada siswa yang mencapai kriteria sangggat tinggi. Hal ini menyebabkan siswa tidak dapat menemukan sendiri pengatahuan yang hendak dicapai dalam proses pembelajaran demikian hal ini berpengaruh pada peningkatan kemampuan berkomonikasi pada hasil belajar.rendahnya hasil belajar di tunjukan melalui tabel 1

Rendahnya tingkat kemampuan berkomunikasi ini berpengaruh pada rendahnya hasil belajar siswa.

Tabel 1

Rendahnya tingkat kemampuan berkomunikasi matematika pada

\begin{tabular}{|l|l|l|l|l|}
\hline No & Interval & Frekuensi & Persentase & Kategori \\
\hline 1 & $90-100$ & 0 & $0 \%$ & $\begin{array}{l}\text { Baik } \\
\text { sekali }\end{array}$ \\
\hline 2 & $75-89$ & 18 & $10 \%$ & Baik \\
\hline 3 & $65-74$ & 14 & $55 \%$ & Cukup \\
\hline 4 & $56-64$ & 12 & $34 \%$ & Kurang \\
\hline & Jumlah & 44 & $100 \%$ & \\
\hline
\end{tabular}

Tabel 1 di atas menujukan tidak terdapat siswa (0\%) dari 44 anak yang terdapat kriteria baik atau dapat di katakan sudah terlihatpeningkatan kemampuan berkomunikasi yang tinggi, terdapat 18 orang siswa $(10 \%)$ yang memperoleh kriteria cukup atau mampu menjawab pertanyaan apabila 
guru bertanya. Adapun di sisi lain terdapat 14 siswa $(55 \%)$ anak yang mendapat kriteria cukup dengan kata lain siswa belum memeliki mental menyatakan pendapat dan masih belum berani bertanya- tanya. Selain itu adapun sebanyak 12 siswa $34 \%$ sama sekali belum terliahat. Siswa belum mampu secara aktif menyakan pendapatnya ataupun bertanya-tanya serta sulit dalam mengerjakan soal. Rendahnya tingkat kemampuan berkomunikasi siswa berdampak pada hasil belajar kelas 5 SD St.Thersia Marsudirini 77

Berpijak pada permasalahan yang terjadi maka rendahnya tingkat ketrampilan berkomonikasi ini disebabkan karena pengguna model pembelajaran yang belum sesuai dengan pembelajaran kurikulum 2013.

Koeswanti (218: 55) Model pembelajaran adalah suatu cara yang didahulukan oleg guru agar suatu proses pembelajaran tercapai sesuai dengan tujuan yang diingingkan

Penggunaan model pembelajaran yang tepat merupakan salah satu penentu keberhasilan dalam kegiatan pembelajaran yang dilakukan oleh guru. Dengan demikian, guru dapat memilih jenis-jenis model pembelajaran yang sesuai demi tercapainya stujuan pembelajaran yang diharapkan.

Komalasari (2010: 58) menyebutkan Jenisjenis model pembelajaran yang daapat digunakan dalam pembelajaran anatar lain : (1) Model pembelajaran berbasis masalah (Problem Based Learning). (2) Model pembelajaran kooperatif (Cooperative Learning) (3) Model Pembelajaran berbasis proyek (Project based Learning) (4) Model pemelajaran Berbasis kerja. (5) Model pembelajaran konsep (Cancept Learning) (6) Model pembelajaran nilai (Value Learning).

Berdasarkan jenis-jenis model pembelajaran diatas model Model pembelajaran berbasis masalah (Problem Base Learning) merupakan salah satu penentu keberhasilan dalam kegiatan pembelajaran.
Menurut Slameto (2011: 7) Model Problem Base Learning (PBL) Merupakan model pembelajaran yang melatih dan mengembangkan keampuan untuk menyelesaikan masalah yang berorentasi pada masalah autentik dari kehidupan aktual siswa untuk merangsang kampuan berpikir tingkat tinggi.

Senada dengan Slameto, Hosnan (2014: 295) mengemukakan bahwa Model $P B L$ merupakan model pembelajaran dengan pendekatan pembelajaran siswa pada masalah autentik sehingga siswa dapat menyusun sendiri, menumbuhkan kembangkan keterampilan yang lebih tinggi dan inquiry, memandirikan siswa dan meningkatkan kepercayaan diri sendiri.

Berdasarkan latar belakang masalah yang terjadi maka perlu diadakan tindakan perbaikan. Tindakan tersebut dilakukan melalui Penelitian Tindakan Kelas dengan judul Peningkatan Kemampuan Komonikasi dan Hasil Belajar Matematika Melalui Model Problem Based Learning Pada Siswa Kelas 5 SD St.Theresia Marsudirini 77 Salatiga.

\section{METODE}

Arikunto (2011: 58) menyatakan bahwa penilitian tindakan kelas adalah penilitian tindakan yang dilakukan di kelas dengan tujuan memperbaiki dan meningkatkan mutu praktik pembelajaran.

PTK dapat dilakukan secara kolaboratif, artinya dapat berkolaborasi atau bekerjasama dengan guru kelas 5 SD St. Theresia Marsudirini 77 Salatiga dalam melakukan PTK. Adapun kolaborasi yang dimaksud yakni guru dan peneliti mendiskusikan permasalahan penelitian dan menentukan rencana tindakan. Penelitian juga dilakukan secara partisipatir, artinya penulis dengan dibantu rekan seangkatan secara langsung terlibat dalam penelitian. Sebelum dilakukan pembelajaran dengan menerapkan model, Problem 
2013 Peningkatan kemampuan berkomunikasi matematika melalui model PBL di sekolah dasar-Serly Verawati Nubatonis, Henny Dewi Koeswanti, Sri Giarti

Based Learning (PBL) peneliti melakukan observasi terlebih dahulu terhadap kelas yang hendak menjadi subjek penelitian guna menemukan fokus masalah yang akan diangkat. Selanjutnya fokus masalah tersebut didiskusikan dengan guru kelas, dan setelah didapat masalah yang sudah sesuai maka peneliti merancang rencana tindakan dengan menerapkan model pembelajaran Problem Based Learning (PBL) guna meningkatkan kemampuan berrkomonikasi dan hasil belajar siswa.

Teknik pengumpulan data yang digunakan dalam PTK ini adalah teknik tes dan non tes. Sebagaimana namanya teknik tes merupakan teknik pengumpulan data berupa pemberian soalsoal untuk dikerjakan oleh siswa.Sedangkan teknik non tes merupakan teknik pengumpulan data dengan cara mengamati aktivitas guru dan siswa dalam pembelajaran. Instrumen penelitian yang digunakan berupa lembar soal tes dan lembar observasi aktivitas guru dan siswa.

Instrumen pengumpulan data yang digunakan dalam penelitian ini terdiri dari observasi aktifitas siswa dan guru dalam meningkatkan kemampuan berkomonikasi dengan model Problem Based Learning (PBL).Observasi dilakukan yaitu guru kelas 5 di SD St. Theresia Marsudirini 77 salatiga. Untuk mengetahui ketercapaian guru dan siswa dalam menerapkan model Problem Based Learning (PBL).

\section{HASIL DAN PEMBAHASAN}

Secara visual tabel 2 menunjukkan hasil rekapitulasi kemampuan berkomunikasi siswa pada siklus I.

Tabel 2

Hasil Kemampuan Berkomunikasi Matematika Siklus 1

\begin{tabular}{|l|l|l|l|l|}
\hline Skor & $\begin{array}{l}\text { Tingkat } \\
\text { Kemampu } \\
\text { an }\end{array}$ & Kategori & $\begin{array}{l}\text { Frek } \\
\text { uensi }\end{array}$ & $\begin{array}{l}\text { Persen } \\
\text { tase }\end{array}$ \\
\hline $0-34$ & $0-34 \%$ & $\begin{array}{l}\text { Sangat } \\
\text { rendah }\end{array}$ & $\mathbf{5}$ & 11,36 \\
\hline $35-54$ & $35 \%-$ & Rendah & 18 & 40,91 \\
\hline
\end{tabular}

\begin{tabular}{|l|l|l|l|l|}
\hline & $54 \%$ & & & \\
\hline $55-66$ & $55 \%-64 \%$ & Sedang & 9 & 20,46 \\
\hline $65-84$ & $\begin{array}{l}65 \%- \\
84 \%\end{array}$ & Tinggi & 11 & 25,00 \\
\hline $85-100$ & $\begin{array}{l}85 \%- \\
100 \%\end{array}$ & $\begin{array}{l}\text { Sangat } \\
\text { tinggi }\end{array}$ & 1 & 2,27 \\
\hline & Jumlah & & 44 & 100 \\
\hline
\end{tabular}

Berdasarkan tabel 2 menunjukkan bahwa kemampuan komunikasi matematika siswa Kelas 5 SD St.Theresia Marsudirini 77 Salatiga setelah pemberian tindakan berupa pembelajaran dengan model Problem Based Learning menujukan dari 44 siswa, ada 21 siswa $(47,7 \%)$ yang memiliki kemampuan berkomunikasi dengan rincian 5 siswa $(11,36, \%)$ berada dalam kategori sangat rendah, 18 siswa $(40,91 \%)$ berada dalam kategori rendah, 9 siswa $(20,46 \%)$ berada dalam kategori sedang, 11 siswa $(25,00 \%)$ berada dalam kategori tinggi, dan 1 siswa $(2,27 \%)$ berada dalam kategori sangat rendah. Setelah di lakukan analisis selanjutnya dilakukan refleksi. Hasilnya refleksi menunjukkan bahwa hasil kemampuan berkomunikasi matematika siswa kelas 5 belum mencapai indikator kinererja yang telah di tetapkan dengan demikian perlu di adakan tindakan siklus II.

Berikut hasil kemampuan berkomunikasi matematika siswa kelas 5 siklus II.

Tabel 3

Hasil Kemampuan Berkomunikasi Siklus II

\begin{tabular}{|l|l|l|l|l|}
\hline Skor & $\begin{array}{l}\text { Tingkat } \\
\text { kemampuan }\end{array}$ & Kategori & Frekuensi & persentase \\
\hline $0-34$ & $0-34 \%$ & $\begin{array}{l}\text { Sangat } \\
\text { rendah }\end{array}$ & 0 & 0.00 \\
\hline $35-$ & $35 \%-54 \%$ & Rendah & 9 & 20,46 \\
54 & & Sedang & 8 & 18,18 \\
\hline $55-$ & $55 \%-64 \%$ & Tinggi & 23 & 52,27 \\
\hline 64 & & & & \\
\hline $66-$ & $65 \%-84 \%$ & Sangat & 4 & 9,09 \\
\hline $85-$ & $85-100 \%$ & tinggi & & 100 \\
\hline 100 & & & 44 & \\
\hline
\end{tabular}


2014 Peningkatan kemampuan berkomunikasi matematika melalui model PBL di sekolah dasar-Serly Verawati Nubatonis, Henny Dewi Koeswanti, Sri Giarti

Berdasarkan dari hasil pada Tabel 3 menunjukkan bahwa tingkat kemampuan komunikasi matematika siswa Kelas 5 SD St.Theresia Marsudirini 77 Salatiga setelah di lakukan pemberian tindakan siklus II dengan model Problem Based Learning menunjukkan peningkatan. Hal ini nampak bahawa dari 44 siswa Kelas 5 SD St.Theresia Marsudirini 77 Salatiga ada 35 siswa $(79,5 \%)$ yang memiliki kemampuan berkomunikasi dengan rincian; tidak terdapat siswa $(0,00 \%)$ berada dalam kategori sangat rendah, 9 siswa $(20,46 \%)$ berada dalam kategori rendah, 8 siswa $(18,18 \%)$ berada pada kategori sedang, 23 siswa $(52,27 \%)$ berada dalam kategori tinggi, dan 4 siswa $(9,09 \%)$ berada dalam kategori tinggi.

Setelah dilakukan tindakan siklus II dan dilakukan refleksi maka hasil dari tindakan siklus II telah mencapa indikator kinerja yang telah ditetapkan. Dengan demikian tindakan perbaikan berhenti pada siklus II.

Keberhasilan model Probelm Based Learning $(P B L)$ dalam meningkatkan kemampuan berkomunikasi Matematika pada siswa kelas 5 SD St.Theresia Marsudirini 77 Salatiga Tahun Pelajaran 2019/2020 sejalan dengan hasil penelitian dari seperti Andi Aulia Hakim (2016: 10), Rizal Abdurroal (2016: 187) Moh Fikri Bungle (2014: 53), Yunin Nurul Nafiah (2014: 141), Maaruf Fanan (2017: 33), Giarti S (2015), Henny Dewi Koeswanti (2019: 49), Rini, R, \& Mawardi, M (2015), Elita zuliyaningsih (2018: 47), Obaja Dwi Handoko (2018: 235)

\section{SIMPULAN}

Berdasarkan hasil penelitian yang telah dilakukan dapat disimpulkan bahwa model problem Based Learning dapat meningkatkan kemampuan berkomunikasi siswa kelas 5 SD St. Theresia Marsudirini 77 Salatiga tahun pelajaran
2019/2020 sebesar 47,7\% (21 siswa) menjadi 79,5 $\%$ (35 siswa) pada siklus II.

\section{UCAPAN TERIMAKASIH}

Terimakasih kepada Kepala Sekolah SD St.Theresia Marsudirini 77 Salatiga yang telah memberikan kesempatan kepada saya untuk melakukan observasi dan penelitian, dan juga kepad guru kelas 5 yang sudah sangat membantu saya dalam menyelesaikan penelitian ini, terimakasih juga kepada dosen pembimbing atas kerjasamanya selama penyusunan jurnal.

\section{DAFTAR PUSTAKA}

Arikunto, S. (2011). Penelitian Tindakan Kelas. Jakarta: PT Bumi Aksara.

Daryanto. (2014). Pendekatan Pembelajaran Saintifik Kurikulum 2013. Yogyakarta: Penerbit Gava Media.

Widjaja, H. (2008). Komunikasi dan Hubungan Masyarakat. Jakarta: Bumi Aksara.

Suprapto, T. (2011). Pengantar Ilmu Komunikasi dan Peran Manajemen dalam Komunikasi. Jakarta: PT. Buku Seru.

Slameto. (2011). Belajar dan faktor-faktor yang mempengaruhinya. Jakarta: PT Rineka Cipta.

Hutagalung, I.(2017). Pengembangan kepribadian. PT Indeks. Jakarta.

Komalasari, K. (2010). Pembelajaran konsektual dan aplikasi. Rafika Aditama: Bandung.

Suhandi Astuti (2016 Kemendikbud. 2016. Permendikbud No. 22 Tahun 2016

Majid, Abdul dan Rochaman, Chaerul. 2014. Pendekatan Iilmiah Dalam Implementasi Kurikulum 2013. Bandung: PT Remaja Rosdakarya.

Giarti, Sri. 2014. Peningkatan Keterampilan Proses Pemecahan Masalah dan Hasil Belajar Matematika Menggunakan Model PBL Terintegrasi Penilaian Autentik pada Siswa Kelas VI SDN 2 Bengle Wonosegoro. Scholaria. 4 (3), 13-27. 
2015 Peningkatan kemampuan berkomunikasi matematika melalui model PBL di sekolah dasar-Serly Verawati Nubatonis, Henny Dewi Koeswanti, Sri Giarti

Hosan, 2014. Pendekatan Saintifik dan Kontekstual dalam Pembelajaran Abad 21. Bogor: Ghalia Indonesia

Astuti, suhandi. 2017 Supervisi Akdemik untuk Meningkatkan Kompotensi Guru Di SD Laboratorium UKSW. Scholaria. 7(1). 49-59,

Koeswanti Heny Dewi. 2018. Exsperimen model koperatif Learning dalam pembelajaran ketrampilan menulis karya ilmia :satya wacana unversitas 